\title{
MICROGRAPHIA HISTORICA
}

The Study of the History of the Microscope

\section{G. L'E. Turner}

Available from the Royal Microscopical Society

Clarendon House, Cornmarket Street,

Oxford OX1 3HA

90p (including postage) 


\section{The Archives of \\ The Royal Institution of Great Britain}

First Series

\section{THE MINUTE BOOKS OF THE MANAGERS' MEETINGS $1799-1900$}

15 Volumes

Editorial Supervisor: Dr. Frank Greenaway

The Minute Books of the Managers' Meetings provide a chronological key to the extraordinary involvement of the Royal Institution in all aspects of nineteenth-century life.

The direction of the Institution has always been in the hands of its Managers and the minutes of their monthly meetings are a running commentary on the life of science as they saw it.

The events of science are meaningless if not studied in relation to the conditions which gave rise to them and these Minutes are crucial to this understanding. The Managers discussed not only affairs of high scientific policy but also the conditions in which the nineteenth-century scientist worked, problems of funds, committees, servants and equipment.

This invaluable record will help the study of the sociology of science as well as of its psychology and its methods.

\section{THE SCOLAR PRESS LTD}

20 Main Street, Menston, Ilkley, Yorks LS29 6EZ 


\section{Mathematical Thought from Ancient to Modern Times}

\section{MORRIS KLINE}

The author emphasizes the central ideas and great lines of mathematical thought, thus providing the general reader, the professional, and the student with a broad historical panorama and a new perspective on what mathematics is, what it has achieved, and what its purposes are today. Text figures throughout $£ 12$ OUP New York

\section{A Historical Introduction to the Philosophy of Science}

\section{JOHN LOSEE}

Since the time of Plato and Aristotle philosophers have raised questions about the proper evaluation of scientific interpretations. This book is a historical exposition of positions that have been held on such issues as the distinction between scientific inquiry and other types of investigation, the interdependence of observation and theory, and the evaluation of competing scientific theories. Numerous figures £2 paper covers 90p OPUS

\section{The Heart and the Vascular System in Ancient Greek Medicine}

\section{Alcmaeon to Galen}

C. R. S. HARRIS

How was it that in spite of their extensive anatomical and physiological knowledge the ancient Greeks failed to discover the circulation of the blood? With one exception, their knowledge of the vascular system was almost as accurate as that of Harvey. This book explains how their failure to discover the valves in the veins, and their insistence on over-simplified teleological explanations of the physiology of nutrition and respiration, led them astray. 5 text figures $£ 15$

\section{The Computer from Pascal to von Neumann}

HERMAN H. GOLDSTINE

14 photographs 24 text figures 16.25 Princeton University Press

\section{The Copernican Revolution}

Planetary Astronomy in the Development of Western Thought THOMAS S. KUHN

59 text figures paper covers $£ 1.30$ Harvard University Press

\section{OXFORD UNIVERSITY PRESS}




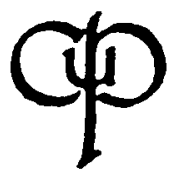

\section{GALENISM}

\section{Rise and Decline of a Medical Philosophy \\ Owsei Temkin}

Drawing on Greek, Latin, and Arabic sources, as well as on modern literature, Dr Temkin traces Galenism as a philosophical, religious, and social phenomenon and shows how it evolved into a predominantly medical philosophy. After examining the systematized teaching of Galenism at medieval universities, he describes the decline of Galen's authority in the sixteenth century and its destruction as a scientific philosophy a century later.

240 pages, 6 plates

\section{a plague of corn}

\section{The Social History of Pellagra}

\section{Daphne A. Roe}

Dr Roe charts the course of the disease from its origins in Europe in the eighteenth century to its present incidence in the emerging nations; she traces the clinical and biochemical research that led to the discovery in the 1930s that the disease is due to a dietary deficiency rather than to an infection or inherited trait, as was previously thought. The ill-fed in Africa and Asia still suffer from the disease. Dr Roe concludes: 'Pellagra will be with us until the dispossessed achieve their right to freedom from want and can choose to eat the food that prevents it."

232 pages, illustrated

E5.20

\section{Cornell \\ University Press 2-4 Brook St. W1}




\section{ANNALS \\ of \\ SCIENCE}

An International Quarterly Review of the History of Science and Technology

Since the Renaissance

This journal was launched in 1936 as an independent English review, dealing with the development of modern science, from its beginnings in the Renaissance down to its extraordinary advances in recent times. As a firmly established journal devoted to the history of science, its field of interest, in accordance with present-day trends, has recently been widened to include articles in French and German, giving it a more international appeal.

The journal is directed to all who are interested in the evolution of science and its impact on the development of related arts and industries. A specimen copy is available on request to the Publishers.

Published Quarterly 4 issues per volume

Annual Subscription: UK and Overseas (surface mail) $\mathbf{1 1 4 . 0 0}$ USA, Canada and Mexico (air-freight) £15.25 (\$38.13)

\section{A Comprehensive Index to ANNALS OF SCIENCE Volumes 1-25 1936-1969}

Compiled by R. E. W. Maddison, Ph.D., F.S.A.

This index has been specially compiled and includes indexes of author, subject, and title of article. The subject index, apart from recording key-words appearing in the titles, also includes lists of portraits and of reviews.

$$
\mathfrak{E 4 . 0 0}(\$ 10.00)
$$

\section{TAYLOR \& FRANCIS LTD \\ 10-14 Macklin Street \\ London WC2B 5NF}

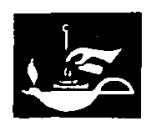




\section{HISTORY OF SCIENCE TITLES FROM MACMILLAN}

\section{SCIENCE AND CONTROVERSY}

\section{A Biography of Sir Norman Lockyer}

Founder Editor of Nature

\section{A. J. Meadows}

'Professor Meadows has written a definitive work on a man who is now seen to be a major British flgure of the nineteenth century.'-J. G. Crowther, New Scientist. £6.95

\section{GALILEO'S INTELLECTUAL REVOLUTION William R. Shea} A perceptive appraisal of the central period of Galileo's work which follows the
evolution of the sun-centred view of the Universe through the mind of its principal advocate $\mathbf{£ 4 . 9 5}$

FRANCIS BACON: PHILOSOPHER OF THE INDUSTRIAL AGE

\section{Benjamin Farrington}

An account of Bacon's thoughts centred on his idea of the transformation of the material conditions of life by science $\mathbf{\$ 4 . 9 5}$

\section{SCIENCE AND POLITICS}

\section{Jean-Jacques Salomon}

An analytical essay based on world-wide information on science policies which presents a new definition of the scientist as opposed to the 'savant'. about $\mathbf{4 . 9 5}$

\section{THE WORLD OF WALTHER NERNST: THE RISE AND FALL OF GERMAN SCIENCE \\ K. Mendelssohn}

A biography of one of Germany's foremost scientists, whose work began in the disciplined period of classical physics and who went on to take a leading part in the great revolution of ideas. about $\mathbf{E 4 . 9 5}$

\section{A HISTORY OF CHEMISTRY}

\section{J. R. Partington}

Vol. I: Earliest Period to A.D. 1500

Part 1: Beginnings of scientific theory in Greece and Egypt

Part 2: Beginnings of alchemy and early chemistry until 1500 (In preparation)

Vol. II: 1500 to 1700

Vol. III: 1700 to 1800 $\mathbf{C 8 . 5 0}$

Vol. IV: 1800 to the present time

Second edition 


\section{THE BRITISH SOCIETY FOR THE HISTORY OF SCIENCE}

THE objects of the Society are to further the study of the history of science, by holding meetings for the reading and discussion of papers, and by facilitating the publication of relevant material.

The British Fournal for the History of Science is the official organ of the Society.

There will generally be a Summer meeting, a Winter meeting, and an Easter meeting of the Society. It is intended that additional meetings be arranged for specific occasions such as important anniversaries.

Membership, which includes a subscription to the Society's Journal, is open to all persons approved by the Council of the Society, and elected at an Ordinary Meeting. The annual subscription is at present $£ 5.00$ (\$15.00) or, for Students, $£ 3.00(\$ 9.00)$.

Those who wish to join the Society should write to the Assistant Secretary, British Society for the History of Science, 47 Belgrave Square, London S.W.I.

Papers for inclusion in the Journal should be submitted to the Hon. Editor, Dr Robert Fox, Department of History, University of Lancaster, Bailrigg, Lancaster, from whom instructions may be obtained concerning the presentation and documentation of papers. All communications on editorial matters, and books for review, should be addressed to the Hon. Editor.

Particulars regarding advertising in the Journal may be obtained from Anthony Merson Ltd., I6 Little Common Road, Bexhill, Sussex.

The British Fournal for the History of Science is published by the Society. At present two parts are published in each year, in June and December, and four parts constitute one volume. The cover of each issue has a consecutive number for ease of collation in subsequent binding; e.g. No. 16 is numbered: Vol. rv Part rv No. I6, and No. 17 is: Vol. v Part I No. 17 . Beginning with the first part of volume VII, to appear in March 1974, the Journal will be published three times a year, in March, July, and November. The three issues published in any one calendar year will then constitute a volume.

Order Forms, with lists of contents of Parts already published, are obtainable from: British Journal for the History of Science, HeAdLEY BROTHERs LTd., AsHFORD, KeNT, ENGLAND, to whom orders for the Journal should be sent.

Particulars of binding costs may also be obtained from HeAdLey Brothers LTD.

c The British Society for the History of Science 1973. 


\section{THE BRITISH JOURNAL FOR THE HISTORY OF SCIENCE}

\section{Volume vi Part III June 1973 No. 23}

William P. D. Wightman: Presidential Address: The Tyranny of Abstractions $\quad 233-246$

RHODA RAPPAPORT: Lavoisier's Theory of the Earth. 247-26o

Mighael Bartholomew: Lyell and Evolution: An Account of Lyell's Response to the Prospect of an Evolutionary Ancestry for Man 26I-303

Note:

Humphry Davy-An Alleged Case of Suppressed Publication

Essay Review

The Kinematics of Circular Motion

Book Reviews

314-332

Books Received

333-335

Collections I: The Turner Collection

336-337

Obituaries

338-340

Notes on Contributors

\section{PUBLISHED BY THE BRITISH SOCIETY FOR THE HISTORY OF SGIENCE}

Registered Office: 47 Belgrave Square, London S.W.1

Brit. J. Hist. Sci. 6 no. 23. Price $£_{2} \cdot 00$. Free to Members of the Society. Published June 1973

PRINTED IN GREAT BRITAIN BY HEADLEY BROTHERS LTD IO9 KINGSWAY LONDON WC2B 6PX AND ASHFORD KENT 